\title{
NEW VADADE VILLAGE PROFILE \& DIRECT RESEARCH FOR DETAILED STUDY ON WATER AND WASTE WATER MANAGEMENT
}

\author{
S.S.Pujari ${ }^{1}$, S.M.Bhosale ${ }^{2}$, A.A.Kulkarni ${ }^{3}$ \\ ${ }^{1}$ PG Scholar, EST Department, Department of Technology, Shivaji University, Kolhapur, Maharashtra, India \\ ${ }^{2}$ Associate Professor, EST Department, Department of Technology, Shivaji University, Kolhapur, Maharashtra, India \\ ${ }^{3}$ Associate Professor, EST Department, Department of Technology, Shivaji University, Kolhapur, Maharashtra, India
}

\begin{abstract}
This study focuses on understanding of the development sector of village of Karveer Tehsil of Kolhapur District, named New Vadade. The research has been carried out through participatory approach by living in the village for time duration of 17 weeks, to understand the rural ecosystem in all its dimension-culture, tradition, governance and administration. The research has created an opportunity to get close to understand the ultimate developmental gaps and needs and created a new managerial knowledge at the service of the rural people. The study has been conducted with the help of social science research tools and methods which include Participatory Rural Appraisal (PRA) activities, household survey, Focus Group Discussions (FGD), Interviews, etc. A detailed analysis of different development sectors of the village has been done, which comprise of sectors like Livelihood, Public Health, Agriculture and Industrial, Education, Road and Public Transportation and Energy. The study also comprised of two directed research components in New Vadade Village; those are 1) Water audit at New Vadade Village area and 2) Provision of sanitation facility in Vadade Village. Apart from this mapping is done of village.
\end{abstract}

Keywords: New Vadade Village, Village Profile, Water Audit, Water Sanitation and Participatory Rural Appraisal.

\section{INTRODUCTION}

The vision of UMA (Unnat Maharashtra Abhiyan) is to put our knowledge, expertise and skills for the benefit of the marginalized and disadvantaged sections of the society. In a country where the majority of its population still resides in rural areas it seems pertinent that it be applied to the heart of this nation. To develop the outlook and the attitude to align development professionals, a course work was designed and at its core lies 17 week fields work in a village.

\subsection{Field Stay Objective}

With this mission in mind, it is expected that we understand issues and identify solutions to it. It is expected that we empathize with people and develop the attitude that is required to work in this sector. The objectives of our study were as follows:

- To understand the village as a system

- Study of various sectors and their analysis

- To understand the issues faced by villagers on a day to day basis

For my study I had selected New Vadadevillage.NewVadade village is located at Karvir Taluka of Kolhapur District in Maharashtra .The Maharashtra Government had started a Dhudhganga Project 30-40 years back in Radhanagari taluka. That time Vadade village got fully merged in project land (prakapgrast). So the village was shifted to Gad Mudshingi. Before 2014 New Vadade was located in Gad Mudshingi and it was part of its
Gram Panchayat .From 25th February 2014 it was separated from Gad Mudshingi and it got its own Gram Panchayat.

\subsection{Structure of Study}

The whole report has been divided in to two major sections. 1) Village Research and 2) Directed Research.

Village Report: The village report is an attempt to understand the life scenario of the village. The research has been done by collecting primary and secondary data through conducting Participatory Rural Appraisal (PRA) activities, surveys and interview and from literature surveys.

Directed Research: The first research focuses on water usage or requirement in the village, that has been done through household survey. The second part of the research looks at providing natural treatment solution to waste water disposed from the villages.

\section{METHODS AND METHODOLOGY}

This chapter discusses the various methods and tools I adopted for the collection of primary and secondary data for the village and directed research.

\subsection{Basic Land Use Map}

The map of New Vadade Gram Panchayat area was studied to get more information about the land use pattern and vegetation cover near the village. New Vadade is situated 
near industrial zone as well as agricultural lands. Apart from this a Base map had been prepared with keeping Google map as reference. It helped me to understand the land use pattern cover of the village. Base map gives a picture of different land usages like residential, industrial, agricultural land, canals and roads. Creating base map also helped me in getting more insight about social and resource mapping, which is part of our PRA activities.

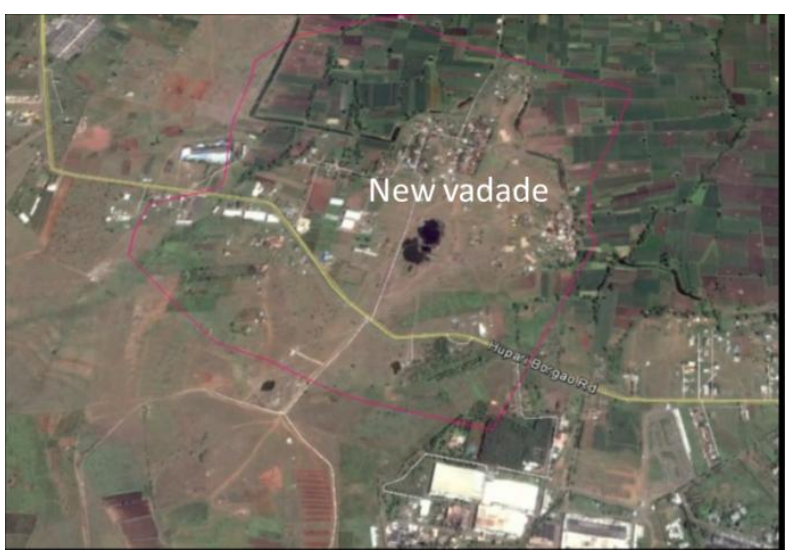

Fig -1: Village Location on Google Image

\subsection{Participatory Rural Appraisal}

The concept of Community is like every day Participatory Appraisal where everyone's views are appreciated, discussed and decisions are taken in the goodwill of the community. Our PRA activities are like just giving a structure to what they already know, which helps me to understand them in a better organised way. So I planned accordingly and kept so many other group gathering activities along with traditional PRA approaches which helped me to create more people participation in all our activities. The techniques used for PRA activities included Resource Map, Social Map, Transect Walk, Venn Diagram, Seasonality \& Problem Ranking.

\subsection{Resource Map and Social Map}

Resource map is a free open source tool that helps you to make better decision by giving you a better insight into the location and distribution of the resources. With resource map we can celibately record, track and analyze resources at glance using a live map.

Doing PRA activities was interesting. For my resource mapping I started the PRA activities from morning. Even though, one has to use all his skills to gather ladies and gents to do this activity, they are so shy that they do not take the chalk /colors. They will just stand at some distance and watch what is happening. This gave me the opportunity to conduct PRA. My plan was to conduct the activities at 11 'o'clock in the morning. So I started early in the morning, At 8 o'clock, after reading some documents related to PRA and group activities in the field trip again, I then covered the area with Torans.

I started with asking people to draw their houses, fields' roads etc. Villagers began with resources one by one like roads, river, canals, wells and bore wells, residential area, farm fields, industries and airport on the outskirt of village etc. Thereafter I started with social mapping where villagers made their houses, school, sugarcane fields, Horticulture near canal and river on the paper I had provided with the rough sketch of the village. They also provided details of the Spinning industries near the village, Racing academy, Airport etc. since many worked in these industries etc.

Children waited for me to take final photographs of the event. When PRA was finished, I distributed the remaining chalks and sketch pen to children who wanted to draw animals and creatures in their own style.

The Resource and Social maps helped me to understand the different resources available inside the village boundary. This community is a mix of farmers who worked in their fields for livelihood and worker community who worked outside the village in industries etc. The living standard of people on an average is good since there are many options available for livelihood

\subsection{Venn Diagram}

If you have ever seen a village located near to city then you would automatically get to know the kind of ease or feasibility this region offers to you for market, education, communication, health, banking and rest of the other things needed for survival.

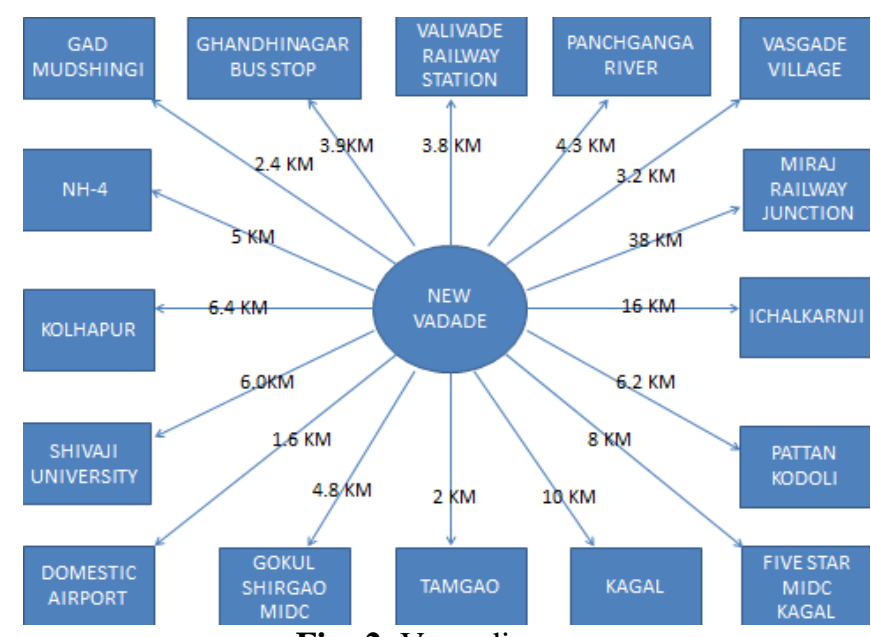

Fig -2: Venn diagram

\subsection{Focus on Group Discussion}

The objective of this activity is to understand the various issues faced by the villagers in their day to day life. Every village has some issues, problems and needs. During our field stay we have observed many such problem faced by villagers. But it is essential to understand their perception towards those. "are they really matter them?" if yes, then it" how much?" and "what is their priority list?".

So all these issues can be prioritized by their importance and urgency. Many issues would be gender specific and some would be age specific, like fetching water from well would be high priority issue for women than men. 
So we have conducted FGD for four groups as Men, women, girls and boys, so that we covered all their issues gender and specifically. During this exercise we asked them to rank the issues faced by them or issues need to be solved according to their importance and urgency. During all FGDs we found that many problems were different for men and women. And even some were same but the cause behind that problem was different like both needed Water, women were finding difficulties while going to the hospital during pregnancy emergency case, since there was no PHC.

\begin{tabular}{|c|c|c|c|c|c|}
\hline \multirow[b]{2}{*}{ Issue. } & \multirow{2}{*}{$\begin{array}{l}\text { blem } \\
\text { TMEN }\end{array}$} & \multirow{2}{*}{$\begin{array}{c}\text { ranking - } \\
\text { KIOMEN }\end{array}$} & \multirow{2}{*}{$\frac{9-11-2016 \text { to }}{\text { Bors }}$} & \multicolumn{2}{|c|}{$11-11-2016$} \\
\hline & & & & GIRL & TOTAL \\
\hline Education & 8 & 2 & 12 & 10 & 32 \\
\hline Road & 2 & & 2 & & 4 \\
\hline Hater - Drinking & 14 & 12 & 12 & 10 & $48 \%$ \\
\hline Water - Agricature & 7 & 6 & 3 & 3 & 19 \\
\hline Toilets. & 1 & - & - & - & 1 \\
\hline Drevinage & 12 & 8 & 9 & 7 & 36 \\
\hline Solid Waste & 10 & 3 & 14 & 9 & 36 \\
\hline Sanitation & 7 & 5 & 12 & 9 & 33 \\
\hline Hospital & 11 & 16 & 7 & 11 & $\{40:$ \\
\hline Play Gzound & 5 & 3 & 7 & 7 & 22 \\
\hline Employment & 3 & 1 & 5 & 6 & 15 \\
\hline Tree plantation & 4 & 2 & 7 & 3 & 16 \\
\hline V. Hospital & 5 & - & - & - & 5 \\
\hline
\end{tabular}

Fig -3: Problem Ranking

\section{VILLAGE PROFILE}

New Vadade is a Village in Karveer Taluka in Kolhapur District of Maharashtra State, India. This village is located at 16040 '7.89" $\mathrm{N}$ and 74018'34.9" E/160 40'17.89" $\mathrm{N}$ and 74018'24.9" E. It belongs to Desh or Paschim Maharashtra region. The area of Village is $239 \mathrm{Ha}$. It is located $9 \mathrm{KM}$ towards East from District headquarters Kolhapur. $18 \mathrm{KM}$ from Karveer taluka. $356 \mathrm{KM}$ from State capital Mumbai.NewVadade Pin code is 416118.

Valivade Rail Way Station, Gur Market Rail Way Station are the very nearby railway stations to New Vadade. Kolhapur Rail Way Station (near to Kolhapur) is another Rail way station reachable from nearby towns. However Sangli Rail Way Station is major railway station $42 \mathrm{KM}$ near to New Vadade

Kolhapur is the nearby by town to New Vadade having road connectivity.
The climate in this region is of the tropical type. The village is $572 \mathrm{~m}$ above sea level and most of the topography is flat. Summers are very hot and winters are moderate. This year the temperature went to 33 to $35 \mathrm{deg}$ Celsius (extreme 38 deg Celsius) in this region.The rainfall has seen a declining trend in the last few years and the rainy days have spread over the course of the year. This has impacted the agriculture negatively. The average rainfall received for the past 3 years has been $540 \mathrm{~mm}$.

\subsection{Demographics}

The secondary data was collected from the government census data. Some relevant data was collected from the Gram Panchayat Office also. In New Vadade there are 356 households as per census data 2011.

Table -1: Census Data 2011

\begin{tabular}{|l|l|l|}
\hline Parameter & $\mathrm{M} / \mathrm{F}$ & $\begin{array}{l}\text { Year } \\
2011\end{array}$ \\
\hline $\begin{array}{l}\text { Number of } \\
\text { Households }\end{array}$ & Total & 356 \\
\hline & Male & 1011 \\
\hline \multirow{4}{*}{$\begin{array}{l}\text { Village } \\
\text { population }\end{array}$} & Female & 828 \\
\cline { 2 - 3 } & $\begin{array}{l}\text { Sex } \\
\text { Ratio }\end{array}$ & 1221 \\
\cline { 2 - 3 } & Total & 1839 \\
\hline
\end{tabular}

\subsection{Educational}

The education status in New Vadade is good. There is a school upto10th standard and there are 2 Anganwadi in village. After assessment the average pass percentage of school is $80 \%$. However for Secondary school education and higher education New Vadade People are dependent on nearby Gad Mudshingi schools. For 11th and 12th students have to move to various places like Kolhapur, Kagal, Ichalkarnji, Pune, Sangli etc.

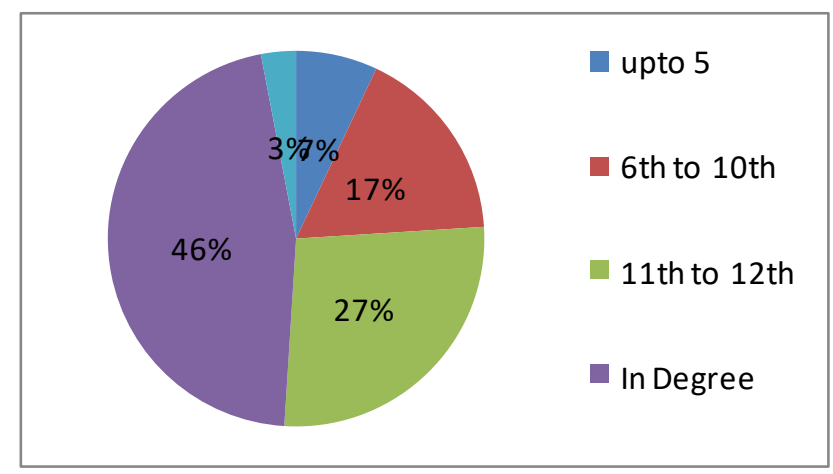

Fig -4: Educational Status

\subsection{Educational Facilities}

New Vadade has 2 Anganwadis and 1 primary school. The table below gives details of the institutions, students, infrastructure and mid-day meal scheme. 
Table -2: School Information

\begin{tabular}{|c|c|c|c|}
\hline & & $\begin{array}{l}\text { Anganwa } \\
\text { dis }\end{array}$ & $\begin{array}{l}\text { Primary } \\
\text { School }\end{array}$ \\
\hline 1 & Public & 2 & 1 \\
\hline 2 & Private & & \\
\hline 3 & Students (Numbers) & $(40+25)$ & 335 \\
\hline 4 & Teachers & 1 each & 13 \\
\hline 5 & Rooms & 1 each & 12 \\
\hline 6 & Helpers & 1 each & None \\
\hline 7 & Building & 1 each & 5 \\
\hline 8 & Salary for Teachers & Rs 5000/- & Rs 35000/- \\
\hline 9 & Salary for Helpers & $\begin{array}{l}\text { Rs 2500/- } \\
-\end{array}$ & \\
\hline \multirow[t]{2}{*}{10} & $\begin{array}{ll}\text { Mid-day meal } \\
\text { Programme }\end{array}$ & Yes & Yes \\
\hline & $\begin{array}{l}\text { Items given in } \\
\text { scheme }\end{array}$ & & $\begin{array}{l}\text { Usal-bhaat, } \\
\text { Khichdi } \\
\text { (depending } \\
\text { on the day } \\
\text { of the week) }\end{array}$ \\
\hline 11 & $\begin{array}{l}\text { Language of } \\
\text { Instruction }\end{array}$ & Marathi & Marathi \\
\hline
\end{tabular}

\subsection{Health}

There is no The Primary Health Centre (PHC) in New Vadade village but in Gad Mudshingi was built in the year 1992. The PHC has 2 ambulances, one of which is donated by the villagers and a lab where blood, urine, sputum tests are done. Diseases like Malaria, HIV, TB and Anemia can be tested in the lab here. They also have an Operation theatre and a breast feeding room. The cases of maternal mortality have reduced and infant mortality is on decline due to the implementation of various schemes. There are no major diseases that are prevalent in this area and only seasonal diseases are observed. The PHC doctor informed that the diseases are specific to seasons. In winters, people suffer from cold and cough and this is observed across all age groups. Fever is observed in summers, this is mostly because people work in the fields in spite of the heat. In monsoon, stomach issues are observed on account of contaminated drinking water.

\subsection{Agricultural and Industrial}

Agriculture is a kind of Job which makes someone independent. But this profession has now become a nonviable activity. Every year the numbers of farmers in India are decreasing. The economy of New Vadade is highly dependent on agriculture. Location on the Deccan Plateau, the rich black soil and the availability of water make highly suitable for agricultural activities. Agriculture is the main contributor to the economy of village. Its sugarcane industry contributes to over $5 \%$ of the sugarcane produced in the country and accounts for a significant share of sugar and baggase produced. The village is also an important center for agro-products like sugar, pulses, chillies, turmeric, and food grains.
The economy of village is highly dependent on the sugarcane industry. The well-known factories are Bhogavati sugar factory, Kumbhkasari sugar factory, and Shri shahu sugar factory

The Industrial area near to New Vadade village are the Kagal 5 star industrial estate comprising 3000 plots, spread over 1100 hectares. The Shiroli Industrial estate covers 260 hectares. Of the total 730 plots in this estate, around 650 plots have been sold. 635 industries are currently functioning in this area. The GokulShirgaon industrial estate is spread over 220 hectares. It has 850 plots of which 800 are sold. 750 industries function in this estate, most of them relating to engineering and foundry.

\subsection{Sanitation and Solid Waste Management}

Most households have private toilets inside or in the immediate vicinity. There are no toilets along the outskirts of the village and these people are dependent on the community toilets. The toilets are properly maintained and clean. The private toilets are mostly dependent on septic tanks and soak pits for waste water disposal. The Gavthan mainly has septic tanks while the farms see more dependence on soak pits. Very few households engage in open defecation. However, it is not completely absent

The population for New Vadade was 1839 in 2011 (Census, 2011). No system for solid waste collection. So they dispose their garbage openly, inside the road side drain and in other open areas. The improper disposal of Solid Waste has led to infestation by rodents throughout the village.

\subsection{Water Supply}

New Vadade village have its own source of water supply. The water source is well; the source is located $1 \mathrm{kms}$ north of Village. The water is taken via $100 \mathrm{~mm}$ pipelines from the well to ESR located in village at ground level $573 \mathrm{~m}$ from MSL and staging height $15 \mathrm{~m}$ having capacity of 30 KL.

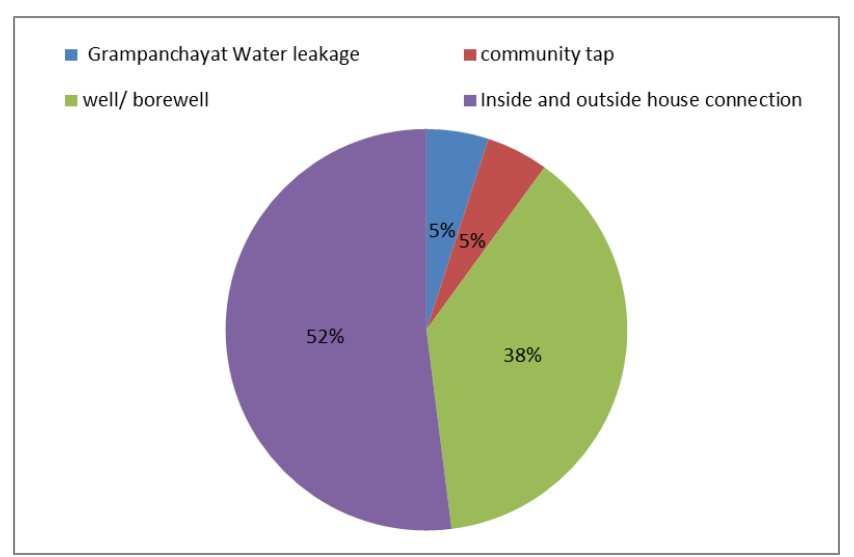

Fig -5: Water supply

The household survey results show that most people are dependent on the scheme for drinking water. In farms, both bore well and open well water is used for drinking, as per availability. The results from the household survey are 
needed to summarize.In year 2015, owing to the low rains from the year before, the drinking water situation has been quite bad. There were periods of 7-10 days when people did not get water from the scheme. Towards the end of the summer, water levels were very low in tube well. This affected not Vadade, but almost every neighboring village has same situation

\subsection{Village Mapping}

For development of Newvadade Village map. I had used a Google Earth is a software program that displays the earth's surface using satellite imagery and aerial photography

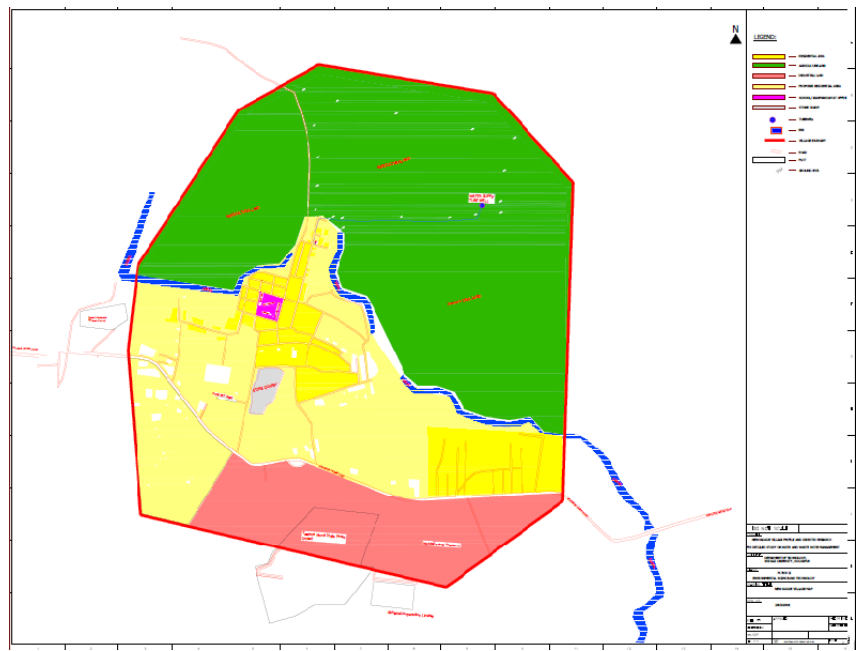

Fig -6: Village Land use Map

\section{DIRECTED RESEARCH}

\subsection{Provision of Sanitation Facility}

The main objective of the whole Directed Research was to come up with a natural treatment plan for the sewage generated in village area. The water audit was used as a tool to estimate the amount of waste water generated in the area at different locations.

It's important to map the locations of waste water generation and map the path in which waste water moves. Plan accordingly to design/provide some natural mode of treatment to the collected waste water.

Steps involved in this process are tabulated below

- Mapping the Septic tanks

- Mapping the flow of waste water

- Calculated the amount of waste water generated with zone

- Planning natural secondary treatment

In village no sewer network is present so all waste water generated from household will disposed in nearest road side drain or natural nalla.

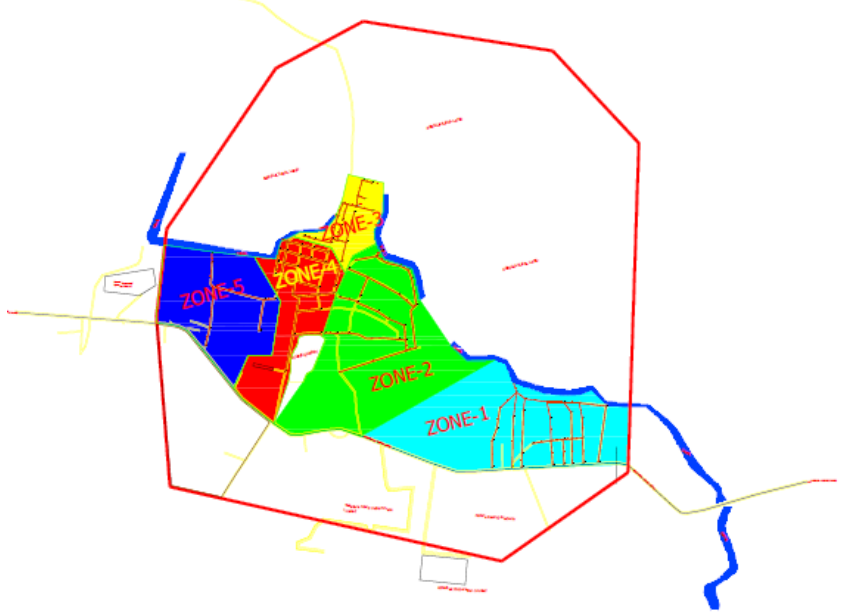

Fig -7: Sewer Zoning

Table -3: Quantity of waste water Generation

\begin{tabular}{|l|l|l|l|l|l|}
\hline $\begin{array}{l}\mathrm{Z} \\
\mathrm{o} \\
\mathrm{n} \\
\mathrm{e}\end{array}$ & Area $(\mathrm{m} 2)$ & $\begin{array}{l}\text { Popu } \\
\text { latio } \\
\mathrm{n}\end{array}$ & $\begin{array}{l}\text { Water } \\
\text { supply } \\
\text { demand } \\
\text { (L/day) }\end{array}$ & $\begin{array}{l}\text { Sewage } \\
\text { flow } \\
\text { (1/ day) }\end{array}$ & $\begin{array}{l}\text { Dispos } \\
\text { al point }\end{array}$ \\
\hline 1 & 245276.81 & 736 & 51492 & 41193.6 & canal \\
\hline 2 & 266742.10 & 92 & 6436.5 & 5149.2 & canal \\
\hline 3 & 49647.91 & 276 & 19309.5 & 15447.6 & canal \\
\hline 4 & 117902.66 & 644 & 45055.5 & 36044.4 & canal \\
\hline 5 & 150050.00 & 92 & 6436.5 & 5149.2 & canal \\
\hline \multicolumn{2}{|l|}{ Total } & 1839 & 128730 & 102984 & \\
\hline
\end{tabular}

\subsection{Observations and Recommendations}

From Zone 1 to5 waste water is going to canal. The water in this canal will remain till December, The water in the canal is mainly used for agriculture purpose, they lift water from the canal in the time of summer to grow fodder to the cattle, hence there is no direct problem in dumping the waste water to this canal.

It is important accommodate a constructed wetland which uses the natural processes of exchange between the root, soil and surrounding microbes to treat organic and inorganic pollutants present in the sewage. The flowering plant like Canna can be used in this wetland, or any similar kind of plant available in local environment can be selected.

After Zone 3 and Zone 4, Zone 5 receives the maximum amount of waste water, and as we conducted the survey in rainy season we saw waste water entering the canal. But it is not the case whole year, in winter and summer, this water will be diverted to the agricultural land in the area. Though waste water goes to canal in rainy season it will be diluted in canal's water (its already treated water from septic tank, $30 \%$ of the contaminants are removed in septic tank itself, so if dilution is more than 1:8 then there is no problem). According to our observation there is no need of natural treatment system in area. Wetland system plants can be used near the outlet so that the foul odour will be reduced. 


\subsection{Water Audit}

As village has its own water supply system in the its own area it was important to understand the supply network of the village which include the sources of water as well as supply for various uses like agriculture, Industrial, animal cleaning, household use etc,. For understanding supply network, it is easy when it is metered because at the end of the month it is easy to get the quantity supplied and number of people using the water supplied, hence it will be easier to estimate the lpcd supplied. However in case of unmetered systems like New Vadade village with various uses it was necessary to carry out the household survey for understanding the domestic usage. It is necessary to determine the water use in each fixture. Flow rates of taps needs be calculated with the help of a measurable container and the stopwatch to measure the discharge rate of faucets, for knowing the use per flush one needs to look at the capacity of flush tanks, and number of uses needs to be recorded.

For transmission level survey from the source to the ESR was done and for distribution network a survey of individual users as households was done. It was found that the village did not have a water supply scheme designed for some area in place hence the study carried out focuses on four steps 1) understanding the layout with respect to water sources 2) mapping the supply network 3) mapping the distribution network which includes ESR Monitoring and 4) household survey to know the end user consumption.

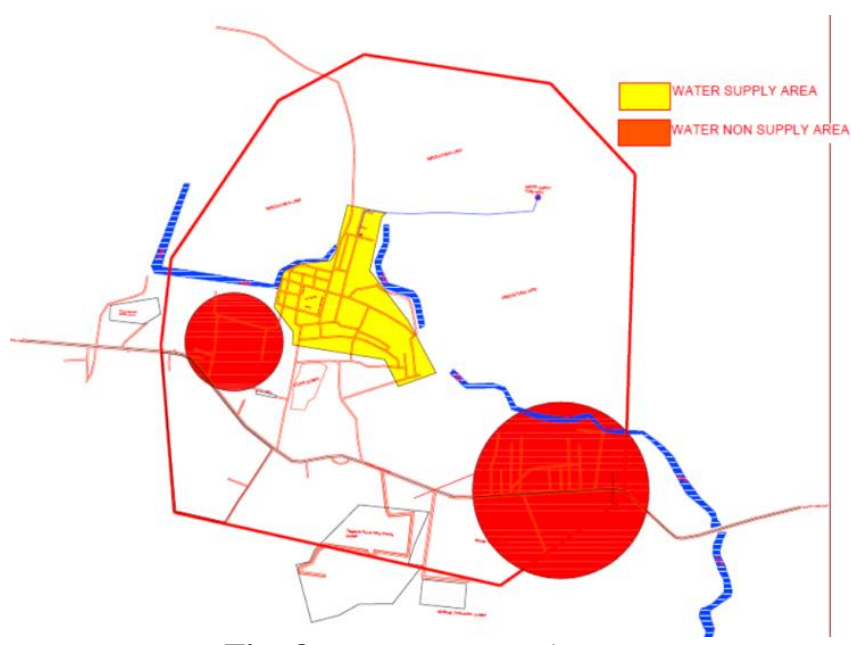

Fig -8: Non water supply area

A format for household survey was prepared referring to the literature which includes tooth brushing, washing hands and face, shaving, cooking, dish washing, gardening, house cleaning, washing clothes, bathing, toilet water use, washing vehicles and also column regarding flow rate, duration of use, number of uses per day, quantity per use were also provided (refer annexure). The village is divided for convenience of analysis. It was decided not to go and shoot questions at residents and fetch garbage answers. So it was planned to go to each resident's house and explain the format to them and monitor their consumption for next 3-4 days and at the end we told them to fill the form on their own, based on conscious observation made by them about their consumption pattern. For people who were not able to read English, we explained and wrote the form in Marathi and told them to follow the same procedure. Though 60 families out of 356 families (to which forms were distributed) didn't fill the form, but they had taken a look at their consumptions and were confident while telling their usage. This method worked well.

Table -4: water supply quantity per region

\begin{tabular}{|l|l|l|l|l|}
\hline Source & Region & No of houses & Population & $\begin{array}{l}\text { Supply } \\
\text { (liter) }\end{array}$ \\
\hline ESR & 1 & 18.00 & 72 & 5040 \\
\hline ESR & 2 & 15.00 & 60 & 4200 \\
\hline ESR & 3 & 17.00 & 68 & 4760 \\
\hline ESR & 4 & 15.00 & 60 & 4200 \\
\hline ESR & 5 & 14.00 & 56 & 3920 \\
\hline ESR & 6 & 20.00 & 80 & 5600 \\
\hline ESR & 7 & 20.00 & 80 & 5600 \\
\hline ESR & 8 & 15.00 & 60 & 4200 \\
\hline ESR & 9 & 13.00 & 52 & 3640 \\
\hline ESR & 10 & 15.00 & 60 & 4200 \\
\hline ESR & 11 & 15.00 & 60 & 4200 \\
\hline ESR & 12 & 20.00 & 80 & 5600 \\
\hline Total & 197.00 & 788 & 55160 \\
\hline
\end{tabular}

It has been noted that the main valve near the ESR is leaking continually (average10 liters per minute), and leakage in taps of resident was evident (60 taps with average 12 liters per hour). These were the major visible leakage points observed in the network.

Table -5: water leakage

\begin{tabular}{|l|l|l|l|l|l|l|}
\hline & Location & \multicolumn{2}{|l|}{$\begin{array}{l}\text { Flow } \\
\text { rate } \\
\text { (liter) }\end{array}$} & $\begin{array}{l}\text { suppl } \\
\text { y Hr }\end{array}$ & $\begin{array}{l}\text { Total } \\
\text { leakag } \\
\text { e } \\
\text { (liter) }\end{array}$ & $\begin{array}{l}\text { Remar } \\
\mathrm{k}\end{array}$ \\
\hline $\begin{array}{l}\text { Pumping } \\
\text { main joint } \\
\text { near nalla }\end{array}$ & 5 & $\begin{array}{l}\mathrm{per} \\
\mathrm{mi}\end{array}$ & 6 & 1800 & $\begin{array}{l}\text { No } \\
\text { action }\end{array}$ \\
\hline $\begin{array}{l}\text { Air valve on } \\
\text { pumping } \\
\text { main }\end{array}$ & 1 & $\begin{array}{l}\mathrm{per} \\
\mathrm{mi} \\
\mathrm{n}\end{array}$ & 6 & 360 & $\begin{array}{l}\text { No } \\
\text { action }\end{array}$ \\
\hline 3 & $\begin{array}{l}\text { Distribution } \\
\text { valve -4 }\end{array}$ & 2 & $\begin{array}{l}\mathrm{per} \\
\mathrm{mi}\end{array}$ & 3 & 360 & $\begin{array}{l}\text { No } \\
\text { action }\end{array}$ \\
\hline 4 & $\begin{array}{l}\text { Outlet valve } \\
\text { ESR }\end{array}$ & 10 & $\begin{array}{l}\mathrm{per} \\
\mathrm{mi} \\
\mathrm{n}\end{array}$ & 6 & 3600 & $\begin{array}{l}\text { Repair } \\
\text { ed on } \\
15 / 4\end{array}$ \\
\hline & $\begin{array}{l}\text { per } \\
\text { Tap } \\
\text { resident }\end{array}$ & 12 & $\begin{array}{l}\mathrm{n} \\
\mathrm{n}\end{array}$ & 3 & 2160 & $\begin{array}{l}\text { No } \\
\text { action }\end{array}$ \\
\hline & $\begin{array}{l}\text { School/ Gram } \\
\text { Panchayat/ } \\
\text { Mandir }\end{array}$ & & & $\begin{array}{l}\text { Appr } \\
\text { ox. }\end{array}$ & 2375 & $\begin{array}{l}\text { No } \\
\text { action }\end{array}$ \\
\hline
\end{tabular}

It's observed that the total ESR consumption 55160 liters whereas average daily discharge from ESR is 65455 liters. 


\subsection{Observations and Recommendations}

- Bagidivasahat and west part of New Vadade village have no water distribution system

- It's significant to note that $86 \%$ of male residents don't use the running tap while shaving.

- Major Leakage near the main Valve of the ESR is causing a wastage around 10295 liters per day, replacement of the leaky parts should be done immediately.

\section{CONCLUSION}

The location show that New Vadade village is very close to a quite developed city Kolhapur. More over employment opportunities is available nearby village within $3 \mathrm{Km}$ are also available. Also electricity is available for $24 \mathrm{hrs}$ and if water scarcity problem solved then this is the biggest resource for development of village.

In view of facilities available in the village and development proposed it may be concluded that New Vadade village is at the verge of becoming aUnnat village as a part of Unnat Maharashtra Abhiyan. .

\section{FUTURE SCOPE OF STUDY}

1. BagadiVasahat is short of water distribution and sanitation (especially water carriage system for human excreta disposal) therefore a project report on detail sanitation scheme for the set village can be studied.

2. Cost estimation of proposed road detailed transportation scheme can be studied.

3. Cost estimate for establishment of post office, bank, employment facilities, police chauki, can be worked out.

4. Details study of cost estimate to meet excess demand of water may be studied.

5. Feasibility study of supply of water from nearby river, located at $6.5 \mathrm{Km}$ distance from the village.

\section{REFERENCES}

[1] Bendahmane Diane B. (1993). Lessons Learned in Water, Sanitation and Health: Thirteen Years of Experience in Developing Countries. Arlington, Virginia: Water and Sanitation for Health (WASH) Project.

[2] Bernard, H. Russell. (2002). Research Methods in Anthropology, Third Edition: Qualitative and Quantitative Methods. Walnut Creek, California: AltaMira Press.

[3] Boot, Marieke T. (1991). Just Stir Gently: The way to mix hygiene education with water supply and sanitation. The Hague, The Netherlands: IRC International Water and Sanitation Centre.

[4] Cairncross, S., Carruthers, I., Curtis, D., Feachem, R., Bradley, D., and Baldwin, G. (1991). Evaluation for Village Water Supply Planning. New York: John Wiley \& Sons.

[5] Dangerfield, Bernard J. (1983). Water Supply and Sanitation in Developing Countries.London: The Institution of Water Engineers and Scientists.
[6] Davis, J., Garvey, G., and Wood, M. (1993). Developing and Managing Community Water Supplies.(Oxfam Development Guidelines No. 8). Oxford: Oxfam.

[7] DR1- General Guidelines for Water Audit and Water Conservation, by Central Water Commission Evaluation of Water Utilisation Directorate, Government of India, Ministry of Water Resources

[8] DR2- Constructed Wetlands Manual by United Nations Human Settlement Programme.

[9] DR3- CPHEEO 2013, Manual on Sewerage and Sewage Treatment Systems, Part A- Engineering. Design and Construction of sewage treatment facilities, Ministry of Urban Development, Government of India.

[10] DR4- Vymazal, J., 2005. Horizontal sub-surface flow and hybrid constructed wetland systems for waste water treatment. Ecological Engineering.

[11] DR5- Vymazal, J., 2011. Constructed wetlands for wastewater treatment: five decades of experience. Environmental Science and Technology

[12] Experiment in Land-Use Allocation with a Geographic Information System by Tomlin, C.D. and K.M. Johnston, Technical Papers, ACSM- ASPRS, St. Louis, Vol. 5, pp. 23-34, 1988.

[13] Hydrogeomorphological studies in the Trichirappalli environs, Tamil Nadu, India using Remote Sensing technology, Map Asia 2000, Sankar, K.

[14] Manou-Savina, Annie. (1998). Benin: Rural Water Supply and Sanitation (Cr. 2622) Project (PADEAR). Paper presented at the Community Water Supply and Sanitation Conference, May 5-8, 1998, The World Bank, Washington, DC.

[15] Okun, Daniel A. (1988). "The Value of Water Supply and Sanitation in Development: An Assessment." In: American Journal of Public Health, vol. 78, no. 11, pp. 1463-1467.

[16] Remote Sensing and GIS Application for Urban Studies; by Subudhi, A. P., Sokhi, B.S. and Roy, P.S., (1999), IIRS publication.

[17] Seminar report of "FOOD SECURITY: Bottom up approach" by Amit Kumar Ukey. Submitted to CTARA, IIT Bombay under completion of TD 694

[18] Simpson-HJbert, Mayling. (1983). Methods for Gathering Socio-cultural Data for Water Supply and Sanitation Projects. Washington, D.C.: The World Bank.

[19] V Khillare V Hyderogeomorphological mapping, GIS Development by Pandey,A.C. and Nathawat, M.S., May 2002. 